$\mathrm{I} 44$ and $336 \mathrm{~h}$ after feeding. Changes in the fatty acid composition of plasma lipids were followed using thin-layer and gas-liquid chromatography. Data for pigs were obtained from animals reared on diets containing varying amounts of linoleic acid (Leat, r 963).

The composition of the various plasma lipids showed striking changes during the period of study. Nevertheless a linear relationship was maintained between certain fatty acids (those altered most by linoleic acid deficiency) of the cholesteryl esters

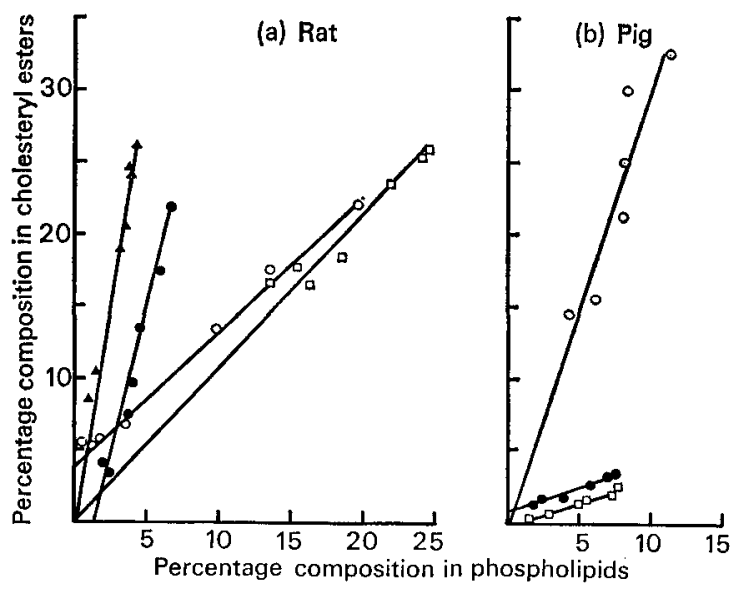

Fig. 1. Relationship between the fatty acids of plasma cholesteryl esters and phospholipids in (a) rats, (b) pigs.

$\Delta, \mathrm{C}_{18: 1} ; \mathrm{O} \longrightarrow \mathrm{O}, \mathrm{C}_{18: 2} ;$ $\square, \mathrm{C}_{20: 3}$

$\longrightarrow, \mathrm{C}_{20: 4}$.

and the phospholipids. Fig. I shows that, in rats, $C_{16: 1}$ and $C_{20: 4}$ acids have a high affinity for esterification as cholesteryl esters whilst $\mathrm{C}_{18: 2}$ and $\mathrm{C}_{20: 3}$ acids have a lower affinity. However, in pigs, $\mathrm{C}_{20: 3}$ and $\mathrm{C}_{20: 4}$ have a very low affinity and $\mathrm{C}_{\mathbf{1 8 : 2}}$ acid a high affinity for cholesteryl esters.

Much evidence suggests that plasma cholesteryl esters are formed in plasma by the transesterification of free cholesterol with the $\beta$-fatty acids of lecithin (Glomset, I968). In both species studied here over $90 \%$ of the $\mathrm{C}_{18: 2}, \mathrm{C}_{20: 3}$ and $\mathrm{C}_{20: 4}$ acids are located in the $\beta$ position of plasma lecithin. It is therefore concluded that the fatty acid composition of plasma cholesteryl esters is determined by (a) the composition of the $\beta$-fatty acids of plasma lecithin and (b) the fatty acid specificity of the $\beta$-acyl transferase, which varies between species.

\title{
REFERENCES
}

Glomset, J. A. (1968). F. Lipid Res. 9, 155.

Leat, W. M. F. (1963). Biochem. F. 89, 44 .

\section{Precursors of aromatic acids found in sheep urine. By A. K. MARTIN, Hannah Dairy Research Institute, Ayr}

The aromatic acids excreted by ruminants are mainly glycine conjugates of benzoic and phenylacetic acids and can be expressed in terms of benzoic acid equivalent 
(BAE). Ruminants excrete between 200 and ${ }_{1} 500 \mathrm{mg} \mathrm{BAE} / \mathrm{kgW}^{\mathbf{0 . 7 5}}$ per $24 \mathrm{~h}$, while omnivorous, carnivorous and herbivorous non-ruminant species only excrete between I4 and $120 \mathrm{mg} \mathrm{BAE} / \mathrm{kgW}^{0.75}$ per $24 \mathrm{~h}$ (Martin, 1969).

The large aromatic acid output of ruminants may arise either as a consequence of metabolism in ruminant tissues or as a result of extensive microbial fermentations occurring in the rumen. Experiments in this laboratory in which sheep have been fasted for periods of up to ro days have shown that, while urinary benzoic acid excretion falls to between 6 and Io $\mathrm{mg} B A E / \mathrm{kgW}^{0.75}$ per $24 \mathrm{~h}$ after 3 or 4 days starvation, urinary phenylacetic acid excretion does not fall below i 5-20 mg BAE/ $\mathrm{kgW} \mathbf{0}^{0.75}$ per $24 \mathrm{~h}$ after ro days starvation.

Quinic and shikimic acids are intermediates in the synthesis of aromatic compounds in plants and are known to accumulate in some plant species. Asatoor ( 1965$)$ has shown that the intestinal microflora of man metabolizes these compounds to benzoic acid. The contents of shikimic, quinic and the related chlorogenic acid (3-0-caffeoylquinic acid) have been determined in perennial ryegrass ( $\mathrm{S} 24)$ harvested at six stages of growth from that of young leaf to mature herbage. Each of these six cuts of grass were given to each of four sheep and the urinary outputs of benzoic and phenylacetic acids (both free and conjugated) determined. Assuming complete metabolism of the precursors (including the caffeoyl moiety of chlorogenic acid) to benzoic acid the urinary output of benzoic acid by sheep consuming $1000 \mathrm{~g} / 24 \mathrm{~h}$ of each cut has been calculated to be: in order of successive increase of maturity of the grass cut, $14^{\circ} \mathrm{O}$, $13 \cdot 9,9 \cdot 3,7 \cdot 1,3 \cdot 2$ and $2 \cdot 2 \mathrm{~g}$.

The average observed outputs of urinary benzoic acid by sheep per $1000 \mathrm{~g} / 24 \mathrm{~h}$ food consumed, expressed as a percentage of the maximum that could have been expected from the precursors considered, were, in order of increasing herbage maturity, I03, 50, 67, 96, I78 and $246 \%$. The average urinary output of phenylacetic acid ( $\mathrm{g} \mathrm{BAE}$ ) per $1000 \mathrm{~g}$ food consumed were, in order of increasing herbage maturity, $\mathrm{I} \cdot 6,3.3, \mathrm{x} \cdot 5,0.4,0.2$ and $0.3 \mathrm{~g}$. Phenylacetic acid excretion was exponentially related to the intake of apparently digestible crude protein and may arise from microbial fermentation of phenylalanine and tyrosine in the rumen (Scott, Ward \& Dawson, I964).

\section{REFERENCES}

Asatoor, A. M. (1965). Biochem. biophys. Acta 1oo, 290.

Martin, A. K. (1969). Br. F. Nutr. 23, 389 .

Scott, T. W., Ward, P. F. V. \& Dawson, R. M. C. (1964). Biochem. F. 90, 12.

A chick biological assay for available tryptophan. By E. J. HARwooD and D. H. Shrimpron, * Unilever Research Laboratory, Colworth/Welwyn, Sharnbrook, Bedford

The present work was begun because no published procedure was known to the authors. After a satisfactory method had been developed the unpublished work of

*Present address: B.O.C.M. Ltd, St. Bridget's House, Bridewell Place, London, EC4. 